\title{
Synthesis and Evaluation of Central Antinociceptive activity of Ring Substituted Chalcones; Molecular Docking Studies with Monoacylglycerol Lipase (MAGL) Enzyme
}

\author{
SHAHEEN BEGUM ${ }^{1 *}$, ARIFA BEGUM ${ }^{1}$ and BHARATHI KOGANTI ${ }^{1}$. \\ Institute of Pharmaceutical Technology, Sri Padmavati Mahila Visvavidyalayam \\ (Women's University), Tirupati 517502, Andhra Pradesh, India. \\ *Corresponding author E-mail: shaheen.pharmchem @ gmail.com \\ http://dx.doi.org/10.13005/ojc/3404024
}

(Received: April 27, 2018; Accepted: June 19, 2018)

\begin{abstract}
Chalcones possess Michael acceptor property due to the presence of $\alpha, \beta$-unsaturated enone moiety in their structure. In the present study, molecular docking was performed to predict binding affinity of ring substituted chalcones with Monoacylglycerol lipase (MAGL), a serine hydrolase enzyme which can inhibited by Michael acceptors such as maleimide derivatives. 3, 4-Dimethoxy derivative, $3 \mathrm{~h}$ with $-44.45 \mathrm{kJmol}^{-1}$ of interaction energy, exhibited highest binding affinity and formed Pi-Sulphur interactions with methionine-123 residue of MAGL enzyme. As MAGL is an emerging target for antinociceptive drug development, ring substituted chalcones were synthesized and evaluated for their central antinociceptive activity using tail immersion and hot plate methods. The results revealed that compound $3 \mathrm{~h}$ chalcone bearing methoxy groups at $3^{\text {rd }}$ and $4^{\text {th }}$ positions of phenyl ring exhibited good antinociceptive activity in both the models. Good correlation was observed between antinociceptive activity and binding affinity toward MAGL in case of compound 3 hour.
\end{abstract}

Keywords: Ring substituted chalcones, Monoacylglycerol Lipase, Hot plate test, Tail immersion test, Molecular docking.

\section{INTRODUCTION}

Pain is now recognized as a global health problem, with an urge for effective and safer therapeutic agents. Pathophysiology of pain is complex despite of the recent advancements that has taken place in the area of molecular and neurobiology ${ }^{1,2}$. Current findings suggest variety of drug targets including ion channels, playing pivotal role in progress of pain signalling [sodium, potassium and transient receptor potential (TRP) channels] and receptors involved in pain perception [imidazoline(I2), adenosine(A1Rs) and cholecystokinin (CCK) $]^{3-5}$. Enzymes of the endocannabinoid cascade, especially, fatty acid amide hydrolase (FAAH), $\alpha, \alpha, \beta$-Hydrolase domain containing 4,6,12 (ABHD-4, ABHD-6, ABHD-12) and Monoacylglycerol lipase (MAGL) which can hydrolyze endocannabonoids, 2-arachidonyl

This is an Open Access article licensed under a Creative Commons Attribution-Non Commercial-Share Alike 4.0 International License (https://creativecommons.org/licenses/by-nc-sa/4.0/), which permits unrestricted Non Commercial use, distribution and reproduction in any medium, provided the original work is properly cited. 
ethanolamine (AEA) and 2-arachnidonyl glycerol (2-AG) are among the promising pain targets and the compounds that alter their respective endocannabinoid levels have been represented as potential antinociceptive agents $s^{6,7}$.

Monoacyl glycerol lipase (MAGL), terminates pharmacological responses of 2-AG by hydrolysing it into arachidonic acid, a familiar proinflammatory mediator and glycerol ${ }^{8}$. 2-AG regulates various neurological and metabolic functions such as neuropathic pain, anxiety and neuromodulation by acting as a full agonist for the cannabinoid receptor type 1 (CB1) receptors ${ }^{9}$. Hence, MAGL inhibition is a promising strategy to treat diseases in which higher 2-AG concentrations would be beneficial, in particular, pain and neuromodulation. MAGL is a member of serine hydrolase class of enzymes. It is highly expressed in brain, particularly at the presynaptic terminals and in areas of brain where CB1 receptors are localized ${ }^{10,11}$. Synthetic drugs such as rivastigmine, saxagliptin, boceprevir, orlistat and $\beta$-lactam antibiotics are few examples of clinically approved inhibitors of human serine hydrolases ${ }^{12,13}$. Literature survey revealed that MAGL enzyme can be inhibited by several chemical entities such as arylthioamides, carbamates, disulphide containing compounds and maleimides. These inhibitors act either by acting on catalytic nucleophilic amino acid Ser-122 (Ser-His-Asp triad) or by forming Michael adduct with sulfhydryl groups of aminoacids (Cys-204\&Cys-242 present in the active site ${ }^{14-16}$.

Chalcones obtained either from natural sources or prepared synthetically, inhibit a broad range of enzymes, to mention a few, inducible nitric oxide synthase (iNOS), lipooxygenase (LOX), xanthine oxidase, tyrosine kinase, monoamine oxidase, soluble epoxide hydrolase, cyclooxygenase-2 (COX-2), angiotensin converting enzyme (ACE) and $\beta$-secreatase ${ }^{17-22}$. Diverse set of therapeutic activities have been ascribed to chalcones such as antitumoral, anticancer, antioxidant, antifungal, antimitotic, chemoprotective, anti-inflammatory, antimicrobial, antinociceptive and antibacterial activities which invigorates interest of medicinal chemists. Presence of the, $\alpha, \beta$-unsaturated enone unit in the chalcone is believed to be highly active, which impart enzyme inhibitory efficiency to this molecule. Michael-addition reaction occurs when chalcones interact with reactive groups of enzymes such as sulfhydryl functionality present in cysteine (Fig.1) which results in the loss of enzymatic activity $^{23-26}$.

Chalcones derived from natural origin or

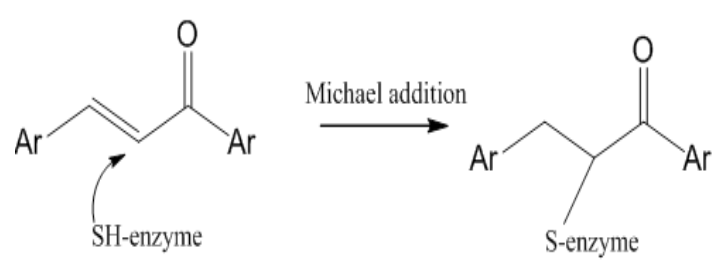

Fig.1. Enzyme inhibition results from interaction of sulfhydrul group and chalcone

synthetic chalcones bearing different substituent groups such as carboxylic acid or acetamide group or substituted urea exhibit peripheral as well as central antinociceptive activity. Mechanism of these potential molecules is not well defined. Literature indicates the probable mechanism might involve COX-2 and iNOS mediated pathways ${ }^{27}$.

In our earlier studies, we have performed molecular docking studies of ring substituted chalcones on iNOS and COX-2 enzymes and reported that these molecules have good binding affinity for both the enzymes, where electronic effects, hydrogen bonding ability have profound influence on the binding interactions. Molecular and pharmacokinetic properties prediction showed that these chalcones have good brain penetration permeability ${ }^{28}$.

In view of the capability of chalcones to interact with variety of enzymes and with the assumption that they may bind and form Michael adduct with cysteinyl groups of MAGL, it was proposed to dock a series of ring substituted (different electron releasing or withdrawing groups on ring B) chalcones with MAGL enzyme. Further, these chalcones were synthesized and their central antinociceptive activity was screened using the tail-immersion and hot-plate tests to find a correlation between in silico and in vivo studies.

\section{MATERIALS AND METHODS}

\section{Molecular Docking studies}

Molecular docking studies on MAGL enzyme was carried out on the crystal structure of MAGL which was retrieved from PDB data bank 
(PDB ID: 3PE6) using CDocker protocol, module of Discovery Studio Version 3.1 (Accelrys). CDocker is a more reliable grid-based protocol wherein CHARMM force fields are applied. While docking the molecules, $10 \AA$ of grid extension was set around the active site of enzyme. Hydrogen atoms were added to the crystal structure of MAGL and all ionisable residues were set at $\mathrm{pH} 7$. For each chalcone (Fig. 2), ten best binding poses were generated. Input site sphere dimensions were set to -11.2454 , $19.8898,-8.42488$ and 11.7564 respectively and binding interactions were analysed. The molecular docking scores were calculated as binding free energies $(\mathrm{kJ} / \mathrm{mol})$.

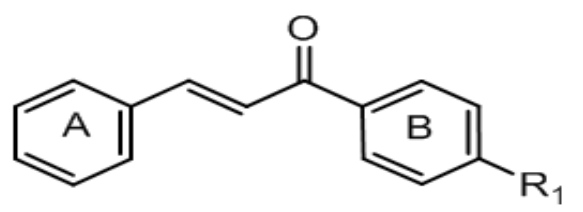

$$
\begin{gathered}
\mathrm{R} 1=\mathrm{H}, 4-\mathrm{F}, 4 \mathrm{Cl}, 2,5-(\mathrm{Cl}) 2,4-\mathrm{NO} 2,4-\mathrm{OH}, 4+\mathrm{OCH} 3,3, \\
\text { 4-( }\left(\mathrm{OCH}_{3}\right)_{2}, 3,4,5-\left(\mathrm{OCH}_{3}\right)_{3}, 4-\mathrm{CH} 3
\end{gathered}
$$

Fig. 2. Chalcones selected for molecular docking studies

\section{Chemistry}

Substituted acetophenones and benzaldehyde were purchased from Merck \& Co., India and
Sigma-Aldrich, USA chemicals. All other chemicals are of AR grade. "Thermonik Precision Melting point cum Boiling point apparatus, Model C-PMB-2 was used to determine the melting points which were uncorrected. Formation of the final compounds was monitored by thin-layer chromatography (TLC). The infrared (IR) spectra were recorded using $\mathrm{KBr}$ pellets on Perkin-Elmer Spectrum-BX-I Infrared Spectrophotometer $\left(\mathrm{cm}^{-1}\right)$. The ${ }^{1} \mathrm{H}$ NMR spectra were recorded in deutero chloroform $\left(\mathrm{CDCl}_{3}\right)$ on Jeol- $400 \mathrm{MHz}$ instrument. Mass $(\mathrm{m} / \mathrm{z})$ spectra were obtained using LCMS-8030 mass spectrometer.

\section{General procedure for the preparation of ring substituted chalcones (3a-j)}

Chalcones were synthesized according to the previously described methodology ${ }^{29}$. A substituted acetophenone $(5 \mathrm{mmol})$ and benzaldehyde $(5 \mathrm{mmol})$ were dissolved in dry methanol $(30 \mathrm{ml})$. To this methanolic solution, $5 \mathrm{ml}$ of sodium hydroxide $(50 \%)$ was slowly added. Stirring was continued (20 min. $^{-1} \mathrm{~h}$ ) at room temperature and to neutralize the contents, ${ }^{1} \mathrm{~N} \mathrm{HCl}$ was added. Reaction time taken for the completion of reactions is mentioned in Table.1. A mixture of ethyl alcohol and water was used for recrystallization. The synthetic procedure and reaction conditions for chalcones are illustrated in scheme 1.<smiles>O=Cc1ccccc1</smiles>

1<smiles>[R]c1ccc(C(C)=O)cc1</smiles>

2

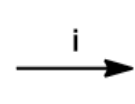

$\mathbf{R}_{\mathbf{1}}=\mathrm{H}, 4-\mathrm{F}, 4-\mathrm{Cl}, 2,5-(\mathrm{Cl})_{2}, 4-\mathrm{NO}_{2}, 4-\mathrm{OH}, 4-\mathrm{OCH}_{3}, 3,4-\left(\mathrm{OCH}_{3}\right)_{2}, 3,4,5-\left(\mathrm{OCH}_{3}\right)_{3}, 4-\mathrm{CH}_{3}$

Scheme 1. Synthesis of chalcones. Reagents and reaction conditions: (i) $50 \% \mathrm{NaOH}, \mathrm{CH}_{3} \mathrm{OH}$, room temperture

\section{Pharmacological studies}

The protocol used to perform the pharmacological activites was approved by institutional animal care and use committee ((1677/ PO/a/12/IAEC/44). Male Swiss Albino mice (25-32 g) were used which were acclimatized to the laboratory for at least $2 \mathrm{~h}$ before testing. The test compounds were suspended well in $1 \%$ sodium carboxymethyl cellulose solution freshly before administration to animals. Tramodol was used as the standard $(10 \mathrm{mg} / \mathrm{kg})$ drug which was administered orally to compare the results of the synthesized compounds.

\section{Hot-Plate Method}

This test was performed in order to measure the latency time (licking the hind- paws/ jumping off 
the hot plate) using hot-plate ${ }^{30}$. The hot plate used in this study was set to a temperature of $55 \pm 1^{\circ} \mathrm{C}$. The saline solution $(0.1 \mathrm{ml} / 10 \mathrm{~g}, \mathrm{p} .0)$ was given to control animals whereas test group animals received synthesized compounds ( $50 \mathrm{mg} / \mathrm{kg}, \mathrm{p} . \mathrm{o}$ ). To reduce the risk of tissue damage or injury, the cut-off time for the latency time was set at 20s.

Table 1: Reaction time taken for completion of different reactions

\begin{tabular}{ccc}
\hline $\begin{array}{c}\text { Compound } \\
\text { No. }\end{array}$ & $\mathrm{R}$ & Reaction time \\
\hline $3 \mathrm{a}$ & $4-\mathrm{H}$ & $>45 \mathrm{~min}$. \\
$3 \mathrm{~b}-3 \mathrm{~d}$ & $4-\mathrm{F}, 4-\mathrm{Cl}, 2,5-(\mathrm{Cl})_{2}$ & $<30 \mathrm{~min}$. \\
$3 \mathrm{e}$ & $4-\mathrm{NO}_{2}$ & $<20 \mathrm{~min}$. \\
$3 f$ & $4-\mathrm{OH}$ & $>50 \mathrm{~min}$ \\
$3 \mathrm{~g}-3 \mathrm{j}$ & $4-\mathrm{OCH}_{3}, 3,4-$ & $>40 \mathrm{~min}$. \\
& $\left(\mathrm{OCH}_{3}\right)_{2}, 3,4$, & \\
& $5-\left(\mathrm{OCH}_{3}\right)_{3}$, & \\
& $4-\mathrm{CH}_{3}$ & \\
\hline
\end{tabular}

\section{Tail-immersion test}

In this animal model, after oral administration of the chalcones or saline, mice were covered using cloth while their tails were immersed in a beaker of hot water $\left(55 \pm 1^{\circ} \mathrm{C}\right)$. The latency (sec.), for the animal to withdraw its tail from hot water was recorded. As long exposure to hot water may lead to tissue inflammation, a cut off of $15 \mathrm{sec}$. was set ${ }^{31}$.

\section{RESULTS AND DISCUSSION}

Chalcones containing different electron withdrawing and electron releasing substituent groups on various positions of $B$ ring (3a-j) were subjected to molecular docking studies. Based on the results observed in these studies, we have synthesized the chalcones and screened them for their potential central antinociceptive activity using pain models such as tail immersion assay and hot-plate tests.

\section{Molecular Docking studies}

MAGL enzyme belongs to $\alpha / \beta$ serine hydrolase super family and comprise of catalytic triad, nucleophilic elbow and oxyanion hole as the main structural elements. Catalytic triad constitutes the residues Ser-122, Asp-239 and His-269 in the the binding pocket. The catalytic site of MAGL is divided into two important regions; Leu-148, Ala-164, Leu-176, Ile-179, Ile- 211, Leu-213, Leu-214 and Val-217 side chains form hydrophobic pocket, while polar groups of Tyr-58, His-121and His-272 side chains, Glu- 53, Arg-57 and Ala- 51 form hydrophilic pocket $^{10-11}$.

$\mathrm{N}$-arachidonyl maleimide (NAM), a reported maleimide derivative (Michael acceptor) with potent MAGL inhibitory activity was used as standard inhibitor for comparing the molecular docking results of the synthesized chalcones. Maleimides acts as Michael acceptors and interact with cysteine residue of MAGL enzyme. Molecular docking studies of NAM with MAGL showed that the long aliphatic chain of the standard inhibitor was found to be located in a way that the terminal alkyl part connects with alkyl portions of Val-191 and Lys-278 via alkyl-alkyl interactions. The polar heterocyclic pyrrole ring of NAM showed $\pi-\pi$ stacking interactions with Phe-159 where as the Pi electrons involve in Alkyl-Pi interactions with Leu-213 and Leu- 214 located near the active site. The interaction energy obtained for NAM was $-60.98 \mathrm{kJmol}^{-1}$ indicating its high affinity towards the enzyme (Figure 3).

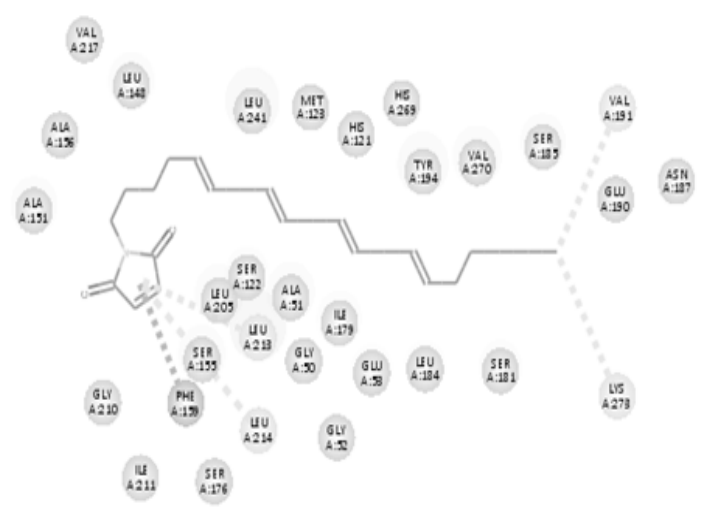

Interactions

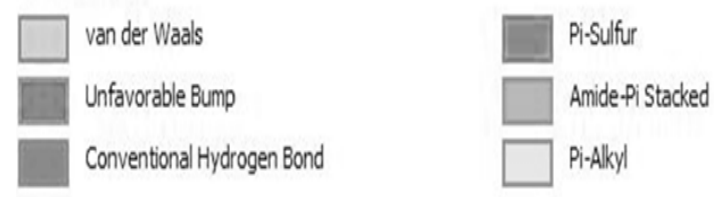

Fig. 3. Binding mode of NAM in the active site of MAGL enzyme

Molecular docking studies of chalcones within the active site of MAGL revealed one particular observation with respect to all chalcones is the formation of S- $\pi$ interactions (Sulphur-Pi) of both the phenyl rings of chalcone with crucial amino acid 
residue Met-123 residing adjacent to Ser-122, part of catalytic triad. Methionine side chains are both lipophilic, flexible and divalent sulphur behaves as a weak negatively polarized atom when interacts with phenyl rings. Ala-126, Ala-127 and Ala-216 were found to interact and have Pi-alkyl interactions with the phenyl rings of chalcones. Amide-Pi stacking interactions were also observed with His-121 and ring $B$ which holds carbonyl group of $\alpha, \beta$-unsaturated carbonyl system. These interactions were observed with all the docked chalcones irrespective of their substituent groups. Obtained results were different from our assumption that chalcones may bind and form Michael adduct with cysteinyl groups of MAGL.

When unsubstituted chalcone was docked in to the binding site of MAGL, Van der Waals interactions were observed between ring $A$ and amino acid residue lle-217 (-38.56 kJ/mol.). Introduction of fluorine increases binding affinity $(-40.23 \mathrm{~kJ} / \mathrm{mol})$, fluorine forms a hydrogen bond with Val-217. Replacement of fluorine with chlorine resulted in further increase in binding affinity $(-40.98 \mathrm{~kJ} / \mathrm{mol})$ indicating that presence of halogens are favourable for binding with the target protein MAGL.

Introduction of electron withdrawing group $\left(-\mathrm{NO}_{2}\right)$ increased the binding affinity for the enzyme $(-41.43 \mathrm{~kJ} / \mathrm{mol})$ when compared to unsubstituted chalcones $(-38.56 \mathrm{~kJ} / \mathrm{mol})$. Among

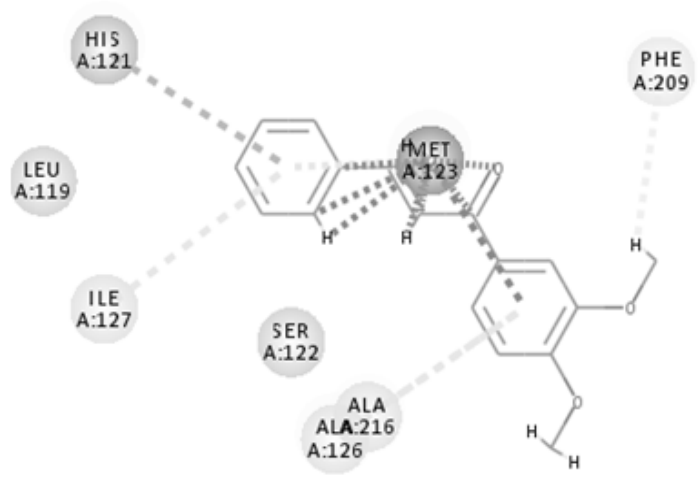

Interactions

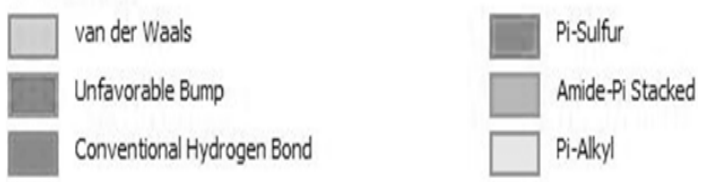

Fig. 4. Binding mode of compound $3 \mathrm{~h}$ in the active site of MAGL the methoxy containing chalcones, 3,4-dimethoxy chalcone exhibited highest binding affinity with the enzyme $(-44.45 \mathrm{~kJ} / \mathrm{mol})$ indicating the importance of substitution on chalcones. Methoxy hydrogens, situated at $3^{\text {rd }}$ position of this chalcone found to form hydrogen bonding with Phe-209. Pi-donor hydrogen bonds were observed between phenyl rings of chalcones and backbone nitrogen atoms of amino acids Ala-126 and lle-127(Figure 4).

Table 2: Docking scores for substituted chalcones (3a-j) with MAGL using CDocker (Discovery Studio)

\begin{tabular}{lccc}
\hline $\begin{array}{l}\text { Compound } \mathrm{R} \\
\text { No. }\end{array}$ & $\begin{array}{c}\text { Interaction } \\
\text { Energy } \\
\left(\mathrm{kJ} \mathrm{mol}^{-1}\right)^{\mathrm{a}}\end{array}$ & $\begin{array}{c}\text { Interacting } \\
\text { Amino acids }\end{array}$ \\
\hline 3a & $4-\mathrm{H}$ & -38.56 & Met-123 \\
3b & $4-\mathrm{F}$ & -40.23 & Met-123, Ala1-26 Ala-216 \\
3c & $4-\mathrm{Cl}$ & -40.98 & Met-123, Ala-126 Ala-216 \\
3d & $2,5-\left(\mathrm{Cl}_{2}\right.$ & -39.24 & Met-123, Ala-126 Ala-216 \\
3e & $4-\mathrm{NO}_{2}$ & -41.43 & Met-123, Ala-126 Ala-216 \\
3f & $4-\mathrm{OH}$ & -40.40 & Met-123, Ala-126Ala-216 \\
3g & $4-\mathrm{OCH}_{3}$ & -43.23 & Met-123, Ala-126 Ala-216 \\
3h & $3,4-\left(\mathrm{OCH}_{3}\right)_{2}$ & -44.45 & Met-123, Ala-126Ala-216 \\
3i & $3,4,5-\left(\mathrm{OCH}_{3}\right)_{3}$ & -42.24 & Met-123, Ala-26Ala-216 \\
3j & $4-\mathrm{CH}_{3}$ & -37.43 & Met-123, Ala-216, Ala126 \\
NAM & - & -60.98 & Phe-159, Val-191,Lys-273, \\
& & & Leu-123, Leu-124 \\
\hline
\end{tabular}

a.The score represents the highest ranking poses obtained from the docking of each compound bound to MAGL enzyme

The results obtained in the docking studies with MAGL indicate that synthesized chalcones have good affinity for this enzyme as they could interact with one of the important amino acid (Ser-122) present in the catalytic triad. Results demonstrated that substitution with either halogens, electron withdrawing and releasing groups are favourable for binding with the enzyme.

\section{Chemistry}

Ring substituted chalcones were prepared by condensation of the appropriate aromatic methyl ketone and simple benzaldehyde. After purification, they were obtained in moderate to good yields. The structures of title compounds were characterized spectral data (IR, ${ }^{1} \mathrm{H}-\mathrm{NMR}$ and Mass)

The IR spectra of the chalcones showed bands due to absorption in the regions 1658- 
$1672 \mathrm{~cm}^{-1}$ ( $\mathrm{C}=\mathrm{O} \mathrm{str}$ ), $1596-1620 \mathrm{~cm}^{-1}$ ( $\mathrm{C}=\mathrm{C} \mathrm{str}$ ). In ${ }^{1} \mathrm{H}-\mathrm{NMR}$ spectra, the coupling constant for vinyl protons was found to be around $15.2-15.6 \mathrm{~Hz}$, confirming the trans-configuration of the prepared chalcones. The aromatic protons showed signals around 7.0-7.9 ppm. The Characteristic molecular ion peaks were obtained $[\mathrm{M}+1]^{+}$corresponding to the molecular weights of the title compounds. Spectral data including IR, ${ }^{1} \mathrm{H}-\mathrm{NMR}$ and Mass of the compounds were in good agreement with the literature values ${ }^{26}$

The synthesized chalcones (3a-j) were tested for their central analgesic activities using hot plate test and tail immersion tests at a dose of 50 $\mathrm{mg} / \mathrm{kg}$ body weight. Tramodol was used as standard drug for comparing the activity of chalcones.

\section{Spectral data}

Compound $-3 a$

Chalcone $[R=H]$ : IR $\left(v_{\max }, \mathrm{cm}^{-1}\right): 1661$ ( $\mathrm{C}=\mathrm{O}$ str), 1605 (C=C str); ${ }^{1} \mathrm{H}-\mathrm{NMR}$ : 6.58-6.97 (d, $1 \mathrm{H}, \mathrm{CH} \alpha=\mathrm{C} J=15.6 \mathrm{~Hz}), 7.11-7.50(\mathrm{~d}, 1 \mathrm{H}$, $\mathrm{C}=\mathrm{CH} \beta, \mathrm{J}=15.6 \mathrm{~Hz}), 7.53-7.89(\mathrm{~m}, 10 \mathrm{H}, \mathrm{Ar}-\mathrm{H}) ; \mathrm{MS}$ : $\mathrm{m} / \mathrm{z} 209.1[\mathrm{M}+1]$

\section{Compound $-3 b$}

3-(4-Fluorophenyl)-1-phenylprop-2-en-1one [R=F]: IR $\left(v_{\max }, \mathrm{cm}^{-1}\right): 1672$ (C=O str), 1620 ( $\mathrm{C}=\mathrm{C}$ str); ${ }^{\mathrm{H}} \mathrm{H}$-NMR: $6.61-7.00(\mathrm{~d}, 1 \mathrm{H}, \mathrm{CH} \alpha=\mathrm{C}$, $\mathrm{J}=15.6 \mathrm{~Hz}), 7.15-7.54(\mathrm{~d}, 1 \mathrm{H}, \mathrm{C}=\mathrm{CH} \beta, \mathrm{J}=15.6 \mathrm{~Hz})$, 7.59-8.01 (m, 9H, Ar-H); MS: m/z 227 [M+1]

\section{Compound $-3 \mathrm{c}$}

3-(4-Chlorophenyl)-1-phenylprop-2-en-1one $[\mathrm{R}=\mathrm{Cl}]$ : IR $\left(v_{\max }, \mathrm{cm}^{-1}\right): 1668$ (C=O str), 1615 ( $\mathrm{C}=\mathrm{C}$ str); ${ }^{\mathrm{H}} \mathrm{H}$-NMR: 6.38-6.77 (d, $1 \mathrm{H}, \mathrm{CH} \alpha=\mathrm{C}$, $\mathrm{J}=15.6 \mathrm{~Hz}), 6.89-7.28(\mathrm{~d}, 1 \mathrm{H}, \mathrm{CH}=\mathrm{CH}, \mathrm{J}=15.6)$, 7.38-7.76 (m, 9H, Ar-H); MS: m/z 243 [M+1]

\section{Compound $-3 d$}

3-(2,5-Dichlorophenyl)-1-phenylprop-2-en1-one [R=2,5-(Cl)2]: IR $\left(v_{\text {max }}, \mathrm{cm}^{-1}\right): 1659(\mathrm{C}=\mathrm{O}$ str), 1596 (C=C str); ${ }^{1} \mathrm{H}-\mathrm{NMR}: 6.89-7.27(\mathrm{~d}, 1 \mathrm{H}, \mathrm{CH} \alpha=\mathrm{C}$, $\mathrm{J}=15.2 \mathrm{~Hz}), 7.36-8.12(\mathrm{~m}, 9 \mathrm{H}, \mathrm{Ar}-\mathrm{H} \& \mathrm{C}=\mathrm{CH} \beta)$; $\mathrm{MS}$ : $\mathrm{m} / \mathrm{z} 277[\mathrm{M}+1]$

\section{Compound $-3 e$}

3-(4-Nitrophenyl)-1-phenylprop-2-en-1-one [R=NO2]: IR ( $\left.v_{\max }, \mathrm{cm}^{-1}\right): 1660$ (C=O str), $1598(\mathrm{C}=\mathrm{C}$ str); ${ }^{1} \mathrm{H}-N M R: 6.74-7.12$ (d, $1 \mathrm{H}, \mathrm{CH} \alpha=\mathrm{C}, \mathrm{J}=15.2 \mathrm{~Hz}$ ),
7.25-7.86 (m, 10H, Ar-H\& C=CH $\beta$ ); MS: m/z 254 $[\mathrm{M}+1]$.

\section{Compound $-3 f$}

3-(4-Hydroxyphenyl)-1-phenylprop-2-en-1one $[\mathrm{R}=\mathrm{OH}]$ : IR $\left(v_{\max }, \mathrm{cm}^{-1}\right): 1674$ ( $\mathrm{C}=\mathrm{O}$ str), 1615 $(\mathrm{C}=\mathrm{C}$ str);1H-NMR : $5.34(\mathrm{~s}, 1 \mathrm{H}, \mathrm{OH})$ 6.78-7.17 (d, $1 \mathrm{H}, \mathrm{CH} \alpha=\mathrm{C}, \mathrm{J}=15.6), 7.25-7.76(\mathrm{~m}, 10 \mathrm{H}, \mathrm{Ar}-\mathrm{H} \&$ $\mathrm{C}=\mathrm{CH} \beta) ; \mathrm{MS}: \mathrm{m} / \mathrm{z} 225[\mathrm{M}+1]$

\section{Compound-3g}

3-(4-Methoxyphenyl)-1-phenylprop-2-en1-one $\left[\mathrm{R}=4-\mathrm{OCH}_{3}\right]$ : $\mathrm{IR}\left(v_{\max }, \mathrm{cm}^{-1}\right): 1671$ ( $\left.\mathrm{C}=\mathrm{O} \mathrm{str}\right)$, 1605 (C=C str); ${ }^{1} \mathrm{H}-\mathrm{NMR}: 3.01\left(\mathrm{~s}, 3 \mathrm{H}, \mathrm{OCH}_{3}\right)$ 6.80-7.19 $(\mathrm{d}, 1 \mathrm{H}, \mathrm{CH} \alpha=\mathrm{C}, \mathrm{J}=15.6 \mathrm{~Hz}), 7.25-7.76(\mathrm{~m}, 10 \mathrm{H}$, $\mathrm{Ar}-\mathrm{H} \& \mathrm{C}=\mathrm{CH} \beta) ; \mathrm{MS}: \mathrm{m} / \mathrm{z} 239[\mathrm{M}+1]$.

\section{Compound $-3 \mathrm{~h}$}

3-(3,4-Dimethoxyphenyl)-1-phenylprop2-en-1-one $\left[\mathrm{R}=3,4-\left(\mathrm{OCH}_{3}\right) 2\right]: \operatorname{IR}\left(v_{\max }, \mathrm{cm}^{-1}\right): 1665$ ( $\mathrm{C}=\mathrm{O}$ str), 1596 (C=C str); ${ }^{1} \mathrm{H}-\mathrm{NMR}$ : 3.05 (s, 6H, $\left(\mathrm{OCH}_{3}\right)$ 2) 6.78-7.17 (d, $\left.1 \mathrm{H}, \mathrm{CH} \alpha=\mathrm{C}, \mathrm{J}=15.6 \mathrm{~Hz}\right)$, 7.25-7.76 (m, $10 \mathrm{H}, \mathrm{Ar}-\mathrm{H} \& \mathrm{C}=\mathrm{CH} \beta$ ); MS: m/z 269 $[\mathrm{M}+1]$.

\section{Compound -3i}

1-Phenyl-3-(3,4,5-trimethoxyphenyl)prop2-en-1-one $\left[\mathrm{R}=\mathrm{CH}_{3}\right]: \mathrm{IR}\left(v_{\max }, \mathrm{Cm}^{-1}\right): 1658(\mathrm{C}=\mathrm{O}$ str), 1621 (C=C str); ${ }^{1} \mathrm{H}-\mathrm{NMR}: 3.00\left(\mathrm{~s}, 6 \mathrm{H},\left(\mathrm{OCH}_{3}\right) 2\right) 3.04$ $\left(\mathrm{s}, 3 \mathrm{H}, \mathrm{OCH}_{3}\right) 6.67-7.06(\mathrm{~d}, 1 \mathrm{H}, \mathrm{CH} \alpha=\mathrm{C}, \mathrm{J}=15.6 \mathrm{~Hz})$, 7.25-7.95 (m, $10 \mathrm{H}, \mathrm{Ar}-\mathrm{H} \& \mathrm{C}=\mathrm{CH} \beta)$; MS: m/z 223 $[\mathrm{M}+1]$

\section{Compound -3j}

1-Phenyl-3-p-tolylprop-2-en-1-one $\left[\mathrm{R}=\mathrm{CH}_{3}\right]$ : FT-IR $\left(v_{\max }, \mathrm{cm}^{-1}\right): 1660(-\mathrm{C}=\mathrm{O}), 1606(-\mathrm{C}=\mathrm{C}-)$; ${ }^{1} \mathrm{H}-\mathrm{NMR}: 1.12\left(\mathrm{~s}, 3 \mathrm{H}, \mathrm{CH}_{3}\right), 6.38-6.77(\mathrm{~d}, 1 \mathrm{H}, \mathrm{CH} \alpha=\mathrm{C}$ $\mathrm{J}=15.2 \mathrm{~Hz}), 7.25-7.76(\mathrm{~m}, 10 \mathrm{H}, \mathrm{Ar}-\mathrm{H}, \& \mathrm{C}=\mathrm{CH} \beta)$; MS: $\mathrm{m} / \mathrm{z} 223[\mathrm{M}+1]$

\section{Central antinociceptive activity}

Ring substituted chalcones displayed peripheral antinociceptive activity in acetic acid induced writhing assay ${ }^{26}$. To evaluate their central antinociceptive activity, tail immersion and hot plate methods were used.

\section{Tail immersion test}

Results of the tail immersion assay showed that most of the chalcones were active in this test. The oral administration of compound $3 \mathrm{~g}$ and $3 \mathrm{~h}$ 
significantly increased the latency time $(9.3 \pm 0.22$ $\& 9.6 \pm 0.28 \mathrm{sec}$ ) to the nociceptive response in this test comparable to that of standard drug tramodol (11.5 $\pm 0.32 \mathrm{sec})$. Unsubstituted chalcone, 3a, was found to be moderately active in this assay $(6.01 \pm 0.62 \mathrm{sec})$. Introduction of halogens such as fluorine and chlorine improved the activity $(7.0 \pm 0.22$ $\& 7.5 \pm 0.30 \mathrm{sec})$. Halogen containing chalcones $3 \mathrm{~b}, 3 \mathrm{c}$ and $3 \mathrm{~d}$ showed good activity in this assay suggesting that presence of this halogen atom is favourable for central antinociceptive activity.

Presence of hydroxyl group on chalcone was unable to exert any promising activity in this assay $(5.01 \pm 0.20 \mathrm{sec})$ whereas replacement of hydroxy group with methoxy functionality (3f) significantly improved the central antinociceptive with latency period of $6.52 \pm 0.67 \mathrm{sec}$. Results of this assay indicates ability of chalcones to act as central antinociceptive agents.

Table 3: Antinociceptive activities of substituted chalcones (3a-j) in different central antinociceptive models

\begin{tabular}{|c|c|c|c|}
\hline \multirow[t]{2}{*}{$\begin{array}{l}\text { S.No. } \\
\text { Control }\end{array}$} & $\mathrm{T}$ & $\begin{array}{l}\text { Tail immersion } \\
\text { test(Latency } \\
\text { period in sec.) }\end{array}$ & $\begin{array}{c}\text { Hot-Plate } \\
\text { test(Latency } \\
\text { period in sec.) }\end{array}$ \\
\hline & - & $3.2 \pm 0.16$ & $2.5 \pm 0.22$ \\
\hline Tramadol & ol & $11.5 \pm 0.22^{*}$ & $8.3 \pm 0.21$ \\
\hline $3 a$ & 4-H & $6.01 \pm 0.62^{*}$ & $3.6 \pm 0.21^{*}$ \\
\hline $3 b$ & $4-\mathrm{F}$ & $7.0 \pm 0.22^{*}$ & $5.3 \pm 0.21^{*}$ \\
\hline $3 c$ & $4-\mathrm{Cl}$ & $7.5 \pm 0.30^{\star}$ & $5.3 \pm 0.21^{*}$ \\
\hline $3 d$ & $2,5-(\mathrm{Cl})_{2}$ & $7.5 \pm 0.30^{*}$ & $4.3 \pm 0.22$ \\
\hline $3 e$ & $4-\mathrm{NO}_{2}$ & $6.01 \pm 0.62$ & $3.6 \pm 0.21^{*}$ \\
\hline $3 f$ & $4-\mathrm{OH}$ & $5.01 \pm 0.20^{*}$ & $3.8 \pm 0.22^{*}$ \\
\hline $3 g$ & $4-\mathrm{OCH}_{3}$ & $9.3 \pm 0.22$ * & $5.3 \pm 0.24^{*}$ \\
\hline $3 h$ & 3,4-( $\left(\mathrm{OCH}_{3}\right)_{2}$ & $9.6 \pm 0.28^{*}$ & $8.0 \pm 0.25^{*}$ \\
\hline $3 i$ & $3,4,5-\left(\mathrm{OCH}_{3}\right)_{3}$ & $7.5 \pm 0.30$ & $7.2 \pm 0.25$ \\
\hline 3j & $4-\mathrm{CH}_{3}$ & $3.2 \pm 0.16^{*} s$ & $3.8 \pm 0.22^{*}$ \\
\hline
\end{tabular}

\section{Hot plate test}

Profile of antinociceptive activity of chalcones in this assay showed that 3 h showed increased latency period up to $8.0 \pm 0.25 \mathrm{sec}$ which is almost comparable to latency of tramodol, $8.3 \pm 0.21$ $\mathrm{sec}$. The next chalcone which was active in this test was 3i, 3, 4, 5-trimethoxy chalcone, which had the latency of $7.2 \pm 0.25 \mathrm{sec}$. The results demonstrate that halogen containing chalcones, $3 b, 3 c$ and $3 d$, which were moderately active in tail immersion assay were found to be moderately active even in hot plate test.

The hot-plate test measures supraspinal responses and the tail-immersion test measures spinal level responses. Hence combined, they represent good models for assessing the central level antinociceptive activity ${ }^{31-33}$. Chalcones showed marked activities in the hot-plate and in the tail-immersion tests (Table. 3), suggesting that they were able to cross blood brain barrier and active on the central nociceptive pathways.

\section{CONCLUSION}

Chalcones, the small organic molecules possess good binding affinity for MAGL enzyme, derivative $3 \mathrm{~h}$ bearing methoxy group at both $3^{\text {rd }}$ and $4^{\text {th }}$ positions showed highest affinity. Chalcones possessing halogens $3 \mathrm{~b}, 3 \mathrm{c}, 3 \mathrm{~d}$ and methoxy groups $3 \mathrm{f}, 3 \mathrm{~g}$ and $3 \mathrm{~h}$ exhibited good central analgesic activity in tail immersion and hot plate methods and highest activity was observed with derivative $3 \mathrm{~g}$, which showed high affinity for MAGL enzyme.

\section{ACKNOWLEDGEMENT}

We are grateful to Department of Science \& Technology-Consolidation of University Research for Innovation and Excellence in Women Universities, Sri Padmavathi Mahila University, for providing FTIR spectrum.

\section{REFERENCES}

1. Borsook, D.; Hargreaves, R.; Bountra, C.; Porreca, F. Sci. Transl. Med., 2014, 6(249), 249.

2. Lee, G.H.; Kim, S.S. Mediators Inflamm., 2016, Article ID 5808215.

3. Li, J.X.; Zhang, Y. Eur. J. pharmacol., 2012, 681(1-3), 1-5.

4. Crow, M.; Denk, F.; McMahon S.B. Genome
Med., 2013, 5, 12-22.

5. Yaksh, T.L.; Sarah, A.W.; Roshni, R.; Linda, S.S. F1000Prime Rep., 2015, 7, 56.

6. Di-Marzo, V. Pharmacol Research., 2009, 60, 77-84.

7. Muccioli, G.G. Drug. Discov. Today., 2010, 15 (11/12): 474-483. 
8. Labar, G.; Wouters, J.; Lambert, D.M. Curr. Med. Chem., 2010, 17(24), 2588-2607.

9. Mulvihill, M.M.; Nomura, D.K. Life. Sci., 2013, 92(8-9), 492-497.

10. Bertrand, T.; Auge, F.; Houtmannn, J.; Rak, K.; Vallee, F.; Mikol, V.; Berne, P.F.; Michot, N.; Cheuret, D.; Hoornaert, C.; Mathieu, M. J. Mol. Biol., 2010, 396, 663-673.

11. Labar, G.; Bauvois, C.; Borel, F.; Ferrer, J.L.; Wouters, J.; Lambert, D.M. Chem. Bio. Chem., 2010, 11, $218-227$.

12. Jonathan, Z.L.; Cravatt, B.F. Chem. Rev., 2011, 111(10), 6022-6063.

13. Bachovchin, D.A.; Cravatt, B.F. Nat. Rev. Drug. Discov., 2013, 11(1): 52-68.

14. Matuszak, N.; Muccioli, G.G.; Labar, G.; Lambert, D.M. J. Med. Chem., 2009, 52(23), 7410-7420.

15. Minkkila, A.; Saario, S.M.; Nevalainen, T. Curr. Top. Med. Chem., 2010, 10, 828-858.

16. Saario, S.M.; Laitinen, J.T. Basic. Clin. Pharmacol. Toxicol., 2007, 101, 287-293.

17. Rojas, J.; Dominguez, J.N.; Charris, J.E.; Lobo, G.; Paya, M.; Ferrandiz, M.L. Eur. J. Med. Chem., 2002, 37, 699-705.

18. Campos-Buzzi, F.; Padaratz, P.; Meira, A.V.; Correa, R.; Nunes, R.J.; Cachinel-Filho, V. Molecules., 2007, 12, 896-906.

19. Reddy, N.P.; Aparoy, P.; Reddy, T.C.; Achari, C.; Sridhar, P.R.; Reddanna, P. Bioorg. Med. Chem., 2010, 18(16), 5807-15.

20. Kong, L.D.; Zhang, Y.; Pan, X.; Tan, R.X.; Cheng, C.H. Cell. Mol. Life. Sci., 2000, 57(3), 500-505.

21. Nerya, O.; Musa, R.; Khatib, S.; Tamir, S.; Vaya, J. Phytochemistry., 2004, 65(10), 1389-1395.
22. Chimenti, F.; Fioravanti, R.; Bolasco, A.; Chimenti, P.; Secci, D.; Rossi, F.; Yanez, M.; Orallo, F.; Ortuso, F.; Alcaro, S. J. Med. Chem., 2009, 52(9), 2818-2824.

23. Mesenzani, O.; Massarotti, A.; Giustiniano, M.; Pirali, T.; Bevilacqua, V.; Caldarelli, A.; Canonico, P.; Sorba, G.; Novellino, E.; Genazzani, A.A.; Tron, G.C. Bioorg. Med. Chem. Lett., 2011, 21, 764-768.

24. Padhye, S.; Ahmad, A.; Oswal, N.; Sarkar, F.H. J. Hematol. Oncol., 2009, 2, 38.

25. Zhuang, C.; Zhang, W.; Sheng, C.; Zhang, W.; Xing, C.; Miao, Z. Chem. Rev., 2017, 117 (12), 7762-7810.

26. Correa, R.; Pereira, M.A.S.; Buffon, D.; Santos, L.; Cechinel Filho, V.; Santos, A.R.S.; Nunes, R. J. Archiv. der Pharmazie., 2001, 334(10), 332-334.

27. Begum, S; Bharathi, K.; Prasad, K.V.S.R.G. J Global Trends Pharm Sci., 2016, 7(3), 3353 - 3361.

28. Begum, S; Bharathi, K.; Mallika, A. International Journal of Pharmacy and Biological Sciences., 2016, 6(2), 100-107.

29. Li, R.; Kenyon, G.L.; Cohen, F.E.; Chen, X.; Gong, B.; Dominguez, J.N.; Davidson, E.; Kurzban, G.; Miller, R.E.; Nuzum, E. O. J. Med. Chem., 1995, 38, 5031-5037.

30. Eddy, N.B.; Leimback, D. Journal. Pharmacol. Exp. Ther., 1953, 107, 385-393.

31. Lingadurai, S.; Nath, L.K.; Karl, P.K.; Besra, S.E.; Joseph, R.V. Afr. J. Tradit. Complement. Altern. Med., 2007, 4, 411-416.

32. Gabra, B.H.; Sirois, P. Peptides., 2003, 24(8), 1131-1139.

33. Soujanya, M.; Rajitha, G. Asian. J. Chem., 2017, 29(11), 2479-2484. 